\title{
Assessing The Relationship Between Liberalization, Ownership And Performance: The Case Of Turkish Banks
}

\author{
Ihsan Isik (E-mail: isik@ rowan.edu), Rowan University, USA \\ Lokman Gunduz, Beykent University, Turkey \\ Osman Kilic (E-mail: osman.kilic@ quinnipiac.edu), Quinnipiac University, USA \\ Dogan Uysal, Selcuk University, Turkey
}

\begin{abstract}
This paper employs a DEA-type Malmquist index approach to evaluate the impact of financial liberalization on the productivity changes of public, private and foreign banks in Turkey during the period between 1981 and 1990. The results indicate that all forms of banks have benefited from financial liberalization. However, foreign banks were found to be the most productive, followed by private banks and public banks respectively. The major source of productivity gains is scale changes for public and private banks and technical progress for foreign banks. It also seems that productivity growth indices of all banks converge towards the end of liberalization period.
\end{abstract}

\section{Introduction}

Over the last two decades financial market deregulation and liberalization has transformed the banking systems of a large number of countries. These reforms are sure to have a profound effect on the development of the financial system in these countries, and their overall macroeconomic performances. Apparently, the policy makers believe that improving the efficiency and performance of financial systems is better implemented through financial liberalization and deregulatory policies aiming at increasing bank competition on price, product, services, and territorial rivalry. However, the empirical evidence on the impact of such polices so far is mixed. Moreover, in a recent study, Altunbas, Evans and Molyneux (2001) draw attention to the relationship between bank ownership and efficiency, and argue that existing literature provides relatively little evidence about the relative efficiency of different ownership forms of financial firms in competitive environments. There are even fewer studies that examine the differential impacts of deregulatory policies on the banks of different forms, particularly in the developing countries.

Most of the survey studies such as Berger, Hunter and Timme (1993), Berger and Humphrey (1997), Berger, Demsetz and Strahan (1998) admit that "most of the empirical research has focused on U.S. banking organizations" and thus "with so few cross-country comparative efficiency studies to draw upon, the results obtained so far should be taken with caution". Evidently, within their 130 and 250-reference long survey papers, respectively, Berger and Humphrey (1997) cite only one Turkish bank study, whereas Berger et al. (1998) cite none. The reason, actually, is the limited existence of empirical studies on Turkish banks, especially in the area of productive efficiency. Therefore, the primary motivation for this study is to contribute to the debate about the productivity of the banking sector and provide empirical evidence that can help new policy formulations in the liberalized / deregulated era.

In the early 1980s Turkey has began to follow financial liberalization policies and undergone a number of major policy changes in bank regulation. For example, elimination of controls on interest rates, a significant 
reduction in directed credit programs, and the relaxation of entry barriers into the banking systems have been the two key elements of the banking related policy changes (Isik and Hassan, 2002). The liberalization program either abolished or relaxed regulations, and the banking industry responded quickly to these developments. Turkish banking system is also interesting because of the diversity of bank ownership form, preponderance of public banks in the oligopolistic and segmented market, and the relationship between macroeconomic environment and banking sector development. Certainly these industry conditions and the type of liberalization/deregulation measures implemented affect the performance of the banks during liberalization period (Berger and Humphrey, 1997). The objective of this study is to measure, and to explain measured variation in the performance of Turkish commercial banks throughout the financial liberalization period. Specifically, utilizing a DEA-type Malmquist total factor productivity change index and 10-year series of data (1981-1990), this paper examines the response of public, private and foreign banks to the liberalization polices.

\section{An overview of the financial liberalization in Turkish banking system}

Throughout the 1980s Turkish financial system has undergone strong legal, structural and institutional changes. Legal and institutional arrangements were introduced to foster the development of the money and capital markets and to deepen the financial system. The first attempt to sell Government securities through periodic auctions started in 1985. The Interbank Money Market for Turkish Lira (TL) was formed in 1986 to allow banks to meet their short-term liquidity needs. The Turkish Privatization Law was enacted in 1986 and a Master Plan was drawn up to undertake the privatization of state economic enterprises. Open market operations and auditing of banks by independent external auditors started in 1987. Unified accounting principles and a standard reporting system were adopted in the same year. Foreign Exchange and Foreign Banknote Markets were established in April 1989. The liberalization of foreign exchange regulations increased banks' foreign exchange transactions. By the end of 1980s, foreign exchange deposits started to surpass the volume of the TL denominated deposits in the sector. During this period, Turkish banks also took an interest in doing business abroad whether by purchasing banks in foreign countries or by opening branches and representative offices, and began increasingly operating in international markets dealing with extensive off-balance sheet activities such as swaps and forward agreements.

In this new business conditions, traditional banks have found themselves in a stern competition not only with recently opened domestic banks but also with foreign banks. In response, those established banks have concentrated on computerization and automation projects to level with the state of art technology of the new foreign and domestic banks. In addition, they have undertaken continuous restructuring and downsizing projects to reduce the size of their branch networks and operations in rural and unprofitable regions. Financial reforms have been successful in attracting new banks into the system. While there were no new entries into the system between 1975 and 1980, the number of banks operating in Turkey has increased stunningly in the 1980s. For instance, excluding failed and merged banks in between, the number of commercial banks increased from just 37 in 1980 to 49 in 1986, and to 56 in 1990. While there were only 4 foreign banks operating in the market between 1977 and 1980, the number increased to 23 by the end of 1990 . Foreign banks have entered the market either by establishing a branch or subsidiary. Despite their small market share, foreign banks have an important place in the Turkish banking system because of the new concepts and practices they have imported.

Before liberalization, Turkish banks were restricted with respect to the explicit interest rates they could pay depositors. In case of interest rate regulation, competition could only take place through quality and convenience to clients, which led to a frantic expansion of branch offices all over the country. Another incentive for branching was the effective negative interest rates in the inflationary environments of the late 1970s. The remarkable growth efforts provided increases in deposits but at the expense of investing in costly new brick-and-mortar branch offices and human resources, having contributed to the overwhelming overhead costs whose adverse impacts on banking have prevailed for decades. Apparently, when market interest rates exceeded the rate allowed by the state, banks often substitute implicit interest payments in the form of improved banking services such as more bank offices or employees per capita or per area.

The evolution of competition in banking has principally featured the de-concentration process in the market as a result of the described loosening of the heavy regulatory environment in the 1980s. While 5 and 10 largest 
banks were accounting for around $75 \%$ and $90 \%$ of all bank deposits, loans, and assets in the early 1970s, their share diminished significantly to about $50 \%$ and $75 \%$, respectively, by the end of the 1980 s. The systematic decline in the share of large banks provides evidence for the small and medium size banks' continuous efforts to grow by expanding their deposit base. One implication is that commercial banking became increasingly competitive over this period.

In spite of the persistent efforts to foster competition among firms, the banking sector with still relatively a few number of banks seems to carry the signs of a typical oligopolistic market. As compared to the American and Western European markets, the financial market in Turkey is extremely oversized, and concentrated by any standard. The extensive branching network, and heavy technology built-up of the existent banks, together with consumer inertia and the goodwill for established institutions, may have been a formidable barrier for potential bank entries in retail banking. As a matter of fact, none of the banks that entered the banking sector during this period has extended its presence beyond the three major cities in the country, Istanbul, Ankara, and Izmir. Although new banks, especially foreign banks, enjoy a better technological position, their entry was important in being innovative in the Turkish context, and improving the quality of human capital (Akkurt et al., 1992; Atiyas and Ersel, 1994).

It can be also argued that benefits of the financial liberalization were partly offset because of the unstable macroeconomic environment and the increased cost of funds to the banking sector. Financial liberalization policies that were implemented in an inflationary environment increased the level of uncertainty and market risk that, in turn, affected banks' lending behavior adversely. Low risk financial instruments, such as short-term working capital for domestic trade, consumer credits, government bonds and treasury bills became the most popular lending forms among commercial banks. Hence financial liberalization changed the composition of the banks' loan portfolio towards short-term lending and public sector debt instruments. Starting from the second half of the 1980's, Turkish banks -particularly foreign and private banks- have invested their bulk of assets in liquid assets in which the share of government securities increased over time. This is also an indication of how quickly the banks adopted themselves to the changing new environment.

\section{Literature review}

Despite the fact that the primary objective of deregulatory policies has been to improve efficiency, the results from different country experiences have reported mixed results. Table 3 tabulates the studies that examined the change in the productivity and/or efficiency of the financial institutions in different countries in reaction to deregulation and financial reforms undertaken. Norwegian banks' productivity and efficiency improved following deregulation (Berg, Forsund, and Jansen; 1992), as did Turkish banks in a more liberalized banking environment (Zaim, 1995). Shyu (1998) also reported upgraded operating efficiency in the Taiwanese banking system after deregulation. Gilbert and Wilson (1998) found that privatization and deregulation improved potential output, as well as productivity, among Korean banks. Thai banks were also benefited from the financial liberalization. Leightner and Lovell (1998) documented that the productivity of all banks operating in Thailand grew at an average of 9 percent per year during the financial liberalization period. In a recent study Sathye (2002) observed that deregulation which started in Australia in early 1980s led to improved productivity in initial years. However a careful analysis of recent period covering the period 1995-1999 resulted in a decline in productivity of banks. Sathye (2002) calls this a 'limit of deregulation' syndrome.

Moreover, Bhattacharyya, Lovell and Sahay (1997) examined association between organizational form and the productive efficiency of Indian banks during the early stages of the ongoing period of liberalization. They found that publicly-owned banks have been the most efficient, followed by foreign-owned banks and privately-owned banks. Examining the effect of banking deregulation on Greek banks, Noulas (2001) reported that the effect of deregulation appears to be positive only for the private banks. However the gap between public banks and private banks was found statistically insignificant. 
Table 1. Studies On The Impact Of Deregulation And Financial Reforms On Bank Performance

\begin{tabular}{|c|c|c|c|}
\hline Country & Method & Author (Date) & Journal \\
\hline Norway & DEA & Berg, Forsund, and Jansen (1992) & Scandinavian Journal of Economics \\
\hline U.S. & SCF & Humphrey (1993) & Journal of Productivity Analysis \\
\hline U.S. & DEA & Grabowski, Rangan \& Rezvanian (1993) & Journal of Economics and Business \\
\hline U.S. & DEA & Elyasiani and Mehdian (1995) & Applied Economics \\
\hline Spain & TFA & Lozano $(1995 a)$ & European J. of Operational Research \\
\hline Turkey & DEA & Zaim (1995) & Applied Financial Economics \\
\hline U.S. & TFA & Humphrey and Pulley (1997) & J. of Money, Credit, and Banking \\
\hline Spain & DEA & Grifell-Tatje and Lovell (1997) & European J. of Operational Research \\
\hline India & DEA & Bhattacharyya, Lovell and Sahay (1997) & European J. of Operational Research \\
\hline Taiwan & DEA & Shyu (1998) & Journal of Emerging Markets \\
\hline Korea & DEA & Gilbert and Wilson (1998) & Journal of Economics and Business \\
\hline Thailand & DEA & Leightner and Lovell (1998) & Journal of Economics and Business \\
\hline Greece & DEA & Noulas (2001) & Managerial Finance \\
\hline Australia & DEA & Sathye (2002) & Managerial Finance \\
\hline
\end{tabular}

${ }^{1}$ Key: DEA (Data Envelopment Analysis), TFA (Thick Frontier Approach), SCF (Stochastic Cost Frontier)

On the contrary, banking efficiency in the U.S. has relatively remained unchanged after the deregulation of the early 1980s (Bauer, Berger, and Humphrey, 1993; Elyasiani and Mehdian, 1995). Also, it was reported in some studies that measured bank productivity declined during the post-deregulation era in the U.S. (Humphrey, 1993; Humphrey and Pulley, 1997). Spain banks' experience was very much like their U.S. counterparts (Grifell-Tatje and Lovell, 1997; Lozano, 1995), the efficiency and productivity in Spanish banking has declined in the deregulated environment contrary to expectations. These results altogether imply that industry conditions prior to deregulation, such as existing excess loan demand in Norway, a desire to rapidly expand market share in Spain, or competition to pay higher deposit interest rates in the U.S., can have important impacts on the efficacy of the reforms undertaken. As reported above, in some cases, deregulation seems to have brought about a reduction in measured productivity rather than an improvement. Thus, the common wisdom, which posits that deregulation always improves efficiency and productivity may not be true for all cases. Industry conditions prior to deregulation and other incentives may intervene (Berger and Humphrey, 1997).

As for the Turkish case, there exist a few empirical studies investigating the episode of the Turkish liberalization (e.g.; Akkurt et al., 1992; Atiyas and Ersel, 1994; Zaim, 1995; Denizer, 1997; Akcaoglu (1998), Kasman, 1998). According to these studies, Turkish banking is now operating in more competitive and open environment than the pre-liberalization period, which should boost the performance of Turkish banks by inducing more efficient and productive operations for banks to survive in more complex and competitive business conditions. Employing a nonparametric approach, Zaim (1995) examined the economic efficiency of Turkish commercial banks at two points in time, one in 1981 and the other in 1990. He provided some initial evidence that the performance of Turkish banks improved in the post-liberalization period because economic efficiency of institutions in 1990 was higher than that in 1981. Denizer (1997), on the other hand, examined the impact of the new entries following the deregulation on the competition of the banking market in Turkey. Using the structure-conduct-performance (SCP) paradigm as a framework of analysis, he also attempted to determine if there is a relationship between market structure and performance of banks. He found that the superior performance was not because of efficient operations but it was because of market power. In other words, high profitability appears to have resulted from the banks' uncompetitive pricing rather than their improved efficiency. He concluded that regulatory and non-regulatory barriers should be removed to promote competition because the entry of small-scale firms alone seems not to have succeeded to increase the competition in banking. Kasman (2002), using a data set from the period 1988-1998, found that although the Turkish commercial banks operated more inefficiently than their U.S. and European peers, the annual inefficiency in the sector decreased over the sample period because of the financial liberalization. His lower efficiency results compared to those of Zaim (1995) could be partly attributed to the different study periods and methodologies utilized. As known, the Turkish banking industry encountered tough business environment in the 1990s with respect to that in the 1980s because of the Gulf War, several currency and macro-economic crises and natural disasters during the last decade. 
In addition to the above studies, there appears to be an ample room for further research. All of the above studies on Turkish banking have invariably focused on efficiency and none of them has investigated the productivity impacts of liberalization. Thus, they have not taken into account the shifts in the production frontier that may take place as a result of technical progress and innovation. In fact, productivity and efficiency concepts refer to different aspects of bank performance. While productivity increases, efficiency may decline between two periods, vice versa. This occurs in case the upward shift in the frontier outweighs the movement by the average bank toward the frontier (Isik and Hassan, forthcoming). A direct comparison of efficiency measures across periods may not be an indicator of absolute improvement or deterioration of efficiency, as it would only show changes in relative efficiency vis-à-vis other banks. The frontier could shift from one period to another because of innovation, financial shock or increased competition in the market. Moreover, there could be substantial bank entries and exits over time, resulting in different samples of banks and thus frontiers across periods. For this reason, in a changing environment, the Malmquist index approach is commonly used to calculate absolute improvement or deterioration in bank efficiency and productivity (Wheelock and Wilson, 1999).

Furthermore, some researchers picked the beginning year of the reforms or a specific year before the reforms as a base year, and another year in the post-deregulation era as a comparison year. However, this leaves the conductor of the research a big initiative, discretion, and arbitrariness. For instance, the improvement in one specific year in the post-liberalization era relative to a year in the pre-liberalization era could be a product of chance. Thus, in order not to let the arbitrary selection of the reference and comparison years impact qualitative results, measurement over longer time periods is needed, and this has not been demonstrated yet (Berger and Humphrey, 1997).

\section{Methodology}

We choose the DEA-type Malmquist productivity index in order to investigate the impact of the financial liberalization on banking productivity and efficiency of Turkish commercial banks. We adopt DEA because of the expressed interest in the Turkish banking industry to control costs in recent years after the liberal policies. Also Berger and Humphrey (1997) report that in the financial institutions literature efficiency studies employing nonparametric approaches outnumber efficiency studies using parametric approaches.

The Malmquist Total Factor Productivity Change index (TFPCH), M, is defined simply as the product of efficiency change (EFFCH), how much closer a bank gets to the efficient frontier (catching up), and technological change (TECHCH), how much the benchmark production frontier shifts at each bank's observed input mix (innovation or shock). EFFCH index takes a value greater than 1 in case of efficiency increase, zero in case of no efficiency change, or less than 1 in case of efficiency decrease, between periods $t$ and $t+1$. Similarly, TECCH attains a value greater than 1 in case of technical progress, zero in case of stagnation, or less than 1 in case of technical regress, between periods $t$ and $t+1$.

We must first determine a model of bank production before estimating productivity change index and its components. Researchers used to compare productivity change mostly by simple cost ratios. However, banking is a complicated and sophisticated business and getting to be more like that as time goes by in this rapidly changing environment. Thus, representation and evaluation of banking performance by either single-input/single-output model, or standard accounting ratios are too simplistic if not unfair. The financial institutions literature made progress in this regard treating banks as going concerns that produce multiple outputs from multiple inputs. Answering the call, Charnes et al. (1978) developed the method popularized as Data Envelopment Analysis (DEA), which generalizes the Farrell (1957) single-input/single-output efficiency measures to the multiple-output/multiple input case.

We adopt the intermediation approach rather than production approach to define the inputs and outputs of banks because we, like majority of the associates in the literature, believe that the former reflects banking production process better. Accordingly, all variables except for the input factor labor are measured in millions of U.S. dollars. We use the following three items as the inputs, which we assume, employed by the Turkish banks to produce their products and services: (1) labor, (2) capital, and (3) funds. The quantity of labor is measured by the number of full- 
time employees on the payroll; capital by the book value of premises and fixed assets; and funds by the sum of deposit (demand and time) and non-deposit funds as of the end of the respective year. The following four items are selected to represent the outputs of the Turkish banks: (1) short-term loans, (2) long-term loans, (3) risk-adjusted off-balance sheet items, and (4) other earning assets. Short-term loans and long-term loans comprise the loans with less than and more than a year maturity, respectively. Off-balance sheet activities include guarantees and warranties (letters of guarantee, bank acceptance, letters of credit, guaranteed pre-financing, endorsements and others), commitments, foreign exchange and interest rate transactions as well as other off-balance sheet activities. Other earning assets consist of loans to special sectors (directed and specialized loans), interbank funds sold and investment securities (treasury bills, government bonds and other securities). Turkish banks began to report their offbalance sheet items to the Banks Association of Turkey starting 1986. Therefore, we developed two models to measure the productivity and efficiency change scores, one with and another without such items. Because offbalance sheet activities are mostly fee earning activities that represent the typical feature of modern banking, we call the model entailing such activities as Non-Classical Model and the alternative model excluding such items as Classical Model.

Because commercial banks and development and investment banks operate in two different environments and are subject to distinct regulations, we did not include development and investment banks in our analysis simply not to fall in the classic fallacy of orange-apple comparison. The data set used in this study was obtained from the Banks Association of Turkey (BAT), which includes all kinds of the banks operating in Turkey (domestic or foreign) as member and publishes their financial statements annually. Our data set encompasses the universe of all forms of banks operating in Turkey between 1981 and 1990.

Table 2. Sample Statistics For Outputs And Inputs Of Public, Private And Foreign Banks (\$US Millions)

\begin{tabular}{|c|c|c|c|c|c|c|c|c|c|}
\hline & \multicolumn{3}{|c|}{ State Banks } & \multicolumn{3}{|c|}{ Private Banks } & \multicolumn{3}{|c|}{ Foreign Banks } \\
\hline & $\#$ & Mean & S.D. & $\#$ & Mean & S.D. & $\#$ & Mean & S.D. \\
\hline \multicolumn{10}{|l|}{ OUTPUTS } \\
\hline \multicolumn{10}{|l|}{ ST Loans } \\
\hline 1981 & 9 & 212.39 & 200.24 & 20 & 169.44 & 296.40 & 6 & 23.48 & 51.44 \\
\hline 1982 & 9 & 236.77 & 195.52 & 20 & 174.93 & 325.12 & 6 & 25.09 & 33.80 \\
\hline 1983 & 9 & 144.99 & 103.77 & 19 & 157.73 & 276.79 & 8 & 22.03 & 29.98 \\
\hline 1984 & 9 & 146.84 & 107.16 & 18 & 144.73 & 269.44 & 10 & 15.93 & 20.80 \\
\hline 1985 & 9 & 193.19 & 223.00 & 18 & 207.24 & 353.24 & 13 & 21.88 & 34.93 \\
\hline 1986 & 9 & 255.28 & 311.99 & 21 & 245.29 & 468.27 & 14 & 19.73 & 37.28 \\
\hline 1987 & 9 & 373.62 & 537.45 & 23 & 246.75 & 464.18 & 17 & 21.51 & 35.11 \\
\hline 1988 & 8 & 290.16 & 294.05 & 23 & 200.69 & 332.86 & 17 & 20.89 & 29.58 \\
\hline 1989 & 8 & 418.64 & 348.32 & 24 & 257.56 & 324.65 & 20 & 27.90 & 38.39 \\
\hline 1990 & $\underline{8}$ & $\underline{568.85}$ & 424.64 & 24 & 399.39 & 497.48 & 21 & 41.78 & 54.24 \\
\hline$\overline{1981}-1986$ & $\overline{9}$ & $\overline{198.24}$ & $\overline{190.28}$ & 19 & 183.23 & 331.54 & $\overline{10}$ & $\overline{21.36}$ & $\overline{34.71}$ \\
\hline $1987-1990$ & 8 & 412.82 & 401.12 & 24 & 276.10 & 404.79 & 19 & 28.02 & 39.33 \\
\hline $1981-1990$ & 9 & 284.07 & 274.61 & 21 & 220.38 & 360.84 & 13 & 24.02 & 36.56 \\
\hline \multicolumn{10}{|l|}{ LT Loans } \\
\hline 1981 & & 55.65 & 139.47 & & 49.17 & 126.58 & & 9.37 & 15.04 \\
\hline 1982 & & 15.77 & 24.88 & & 66.35 & 174.09 & & 12.25 & 21.87 \\
\hline 1983 & & 67.17 & 117.52 & & 62.50 & 170.34 & & 8.75 & 20.75 \\
\hline 1984 & & 27.31 & 30.58 & & 47.57 & 124.94 & & 8.79 & 25.09 \\
\hline 1985 & & 48.82 & 77.05 & & 46.52 & 116.92 & & 6.86 & 21.78 \\
\hline 1986 & & 39.29 & 35.75 & & 47.22 & 144.54 & & 6.51 & 19.54 \\
\hline 1987 & & 68.68 & 65.97 & & 43.29 & 142.52 & & 5.51 & 18.78 \\
\hline 1988 & & 67.37 & 74.35 & & 30.18 & 97.94 & & 4.17 & 12.91 \\
\hline 1989 & & 99.48 & 148.15 & & 34.52 & 109.21 & & 3.85 & 11.51 \\
\hline 1990 & & 109.79 & 136.22 & & 35.68 & 109.01 & & 2.07 & 6.46 \\
\hline $1981-1986$ & & 42.34 & 70.88 & & 53.22 & 142.90 & & 8.76 & 20.68 \\
\hline $1987-1990$ & & 86.33 & 106.17 & & 35.92 & 114.67 & & 3.90 & 12.42 \\
\hline $1981-1990$ & & 59.93 & 84.99 & & 46.30 & 131.61 & & 6.81 & 17.37 \\
\hline
\end{tabular}




\begin{tabular}{|c|c|c|c|c|c|c|}
\hline \multicolumn{7}{|l|}{ OEA } \\
\hline 1981 & 385.91 & 877.58 & 27.50 & 64.40 & 3.03 & 6.94 \\
\hline 1982 & 327.63 & 681.24 & 38.92 & 105.48 & 3.11 & 7.09 \\
\hline 1983 & 305.95 & 621.85 & 31.02 & 88.46 & 1.36 & 2.86 \\
\hline 1984 & 306.66 & 578.98 & 45.17 & 111.27 & 2.36 & 5.74 \\
\hline 1985 & 431.17 & 754.60 & 84.36 & 213.95 & 4.02 & 11.21 \\
\hline 1986 & 609.43 & 1076.38 & 65.16 & 145.28 & 4.67 & 8.77 \\
\hline 1987 & 748.39 & 1185.03 & 92.90 & 157.17 & 9.18 & 17.60 \\
\hline 1988 & 764.17 & 1206.75 & 80.63 & 140.59 & 9.85 & 15.84 \\
\hline 1989 & 1005.80 & 1536.55 & 121.50 & 175.50 & 10.66 & 13.23 \\
\hline 1990 & 1224.58 & $\underline{1957.52}$ & 126.39 & 161.69 & 10.23 & 14.25 \\
\hline$\overline{1981-1986}$ & $\overline{394.46}$ & $\overline{765.11}$ & $\overline{48.69}$ & $\overline{121.47}$ & 3.09 & $\overline{7.10}$ \\
\hline $1987-1990$ & 935.74 & 1471.46 & 105.36 & 158.74 & 9.98 & 15.23 \\
\hline $1981-1990$ & 610.97 & 1047.65 & 71.36 & 136.38 & 5.85 & 10.35 \\
\hline \multicolumn{7}{|l|}{ OFF-B/S } \\
\hline 1986 & 325.39 & 291.36 & 335.20 & 533.17 & 51.80 & 90.64 \\
\hline 1987 & 500.16 & 820.28 & 447.41 & 649.65 & 70.76 & 100.91 \\
\hline 1988 & 484.85 & 629.11 & 347.07 & 417.81 & 43.93 & 73.46 \\
\hline 1989 & 568.20 & 569.29 & 372.55 & 443.49 & 53.47 & 69.47 \\
\hline$\underline{1990}$ & $\underline{635.87}$ & $\underline{596.60}$ & $\underline{480.35}$ & $\underline{523.66}$ & $\underline{62.39}$ & $\underline{74.72}$ \\
\hline$\overline{1981}-1986$ & $\overline{325.39}$ & $\overline{291.36}$ & $\overline{335.20}$ & $\overline{533.17}$ & $\overline{51.80}$ & $\overline{90.64}$ \\
\hline $1987-1990$ & 547.27 & 653.82 & 411.85 & 508.65 & 57.64 & 79.64 \\
\hline \multirow[t]{3}{*}{ 1981-1990 } & 502.89 & 581.33 & 396.52 & 513.56 & 56.47 & 81.84 \\
\hline & \multicolumn{2}{|c|}{ P1: Domestic Public Banks } & \multicolumn{2}{|c|}{ P2: Domestic Private Banks } & \multicolumn{2}{|c|}{ P3: Foreign Private Banks } \\
\hline & Mean & S.D. & Mean & S.D. & Mean & S.D. \\
\hline \multicolumn{7}{|l|}{ INPUTS } \\
\hline \multicolumn{7}{|l|}{ Labor } \\
\hline 1981 & 6559.78 & 9495.22 & 2874.00 & 5112.18 & 339.00 & 611.49 \\
\hline 1982 & 6902.00 & 9844.74 & 3044.50 & 5365.33 & 397.50 & 713.67 \\
\hline 1983 & 7376.67 & 10868.87 & 3221.21 & 5507.52 & 320.13 & 622.51 \\
\hline 1984 & 7677.56 & 11465.81 & 3410.78 & 5673.26 & 266.30 & 544.10 \\
\hline 1985 & 7892.00 & 11674.29 & 3464.61 & 5664.37 & 198.85 & 404.80 \\
\hline 1986 & 8218.56 & 12254.25 & 3084.62 & 5264.46 & 201.21 & 442.38 \\
\hline 1987 & 8710.00 & 12951.21 & 2869.17 & 5024.60 & 160.06 & 362.71 \\
\hline 1988 & 9841.25 & 13385.86 & 2928.35 & 4970.73 & 160.82 & 351.96 \\
\hline 1989 & 10017.63 & 13516.17 & 2849.25 & 4841.43 & 145.20 & 299.13 \\
\hline$\underline{1990}$ & $\underline{10103.13}$ & $\underline{13220.95}$ & $\underline{2838.92}$ & $\underline{4627.76}$ & $\underline{140.48}$ & 295.97 \\
\hline $1981-1986$ & 7437.76 & 10933.86 & 3183.29 & $\overline{5431.19}$ & 287.17 & 556.49 \\
\hline $1987-1990$ & 9668.00 & 13268.55 & 2871.42 & 4866.13 & 151.64 & 327.44 \\
\hline $1981-1990$ & 8329.86 & 11867.74 & 3058.54 & 5205.16 & 232.96 & 464.87 \\
\hline \multicolumn{7}{|l|}{ Capital } \\
\hline 1981 & 25.47 & 33.68 & 7.63 & 12.49 & 1.40 & 1.56 \\
\hline 1982 & 27.36 & 27.81 & 17.93 & 33.76 & 1.54 & 1.27 \\
\hline 1983 & 22.43 & 21.77 & 14.94 & 24.97 & 1.52 & 2.50 \\
\hline 1984 & 22.16 & 23.30 & 16.26 & 24.66 & 1.68 & 2.37 \\
\hline 1985 & 27.44 & 30.20 & 20.00 & 29.31 & 1.75 & 2.36 \\
\hline 1986 & 30.67 & 34.33 & 21.25 & 31.27 & 1.57 & 2.33 \\
\hline 1987 & 41.82 & 40.12 & 23.60 & 38.72 & 1.27 & 2.27 \\
\hline 1988 & 97.73 & 102.51 & 26.91 & 42.78 & 1.29 & 2.55 \\
\hline 1989 & 161.10 & 197.81 & 35.21 & 53.31 & 1.39 & 2.85 \\
\hline 1990 & $\underline{141.60}$ & $\underline{135.52}$ & $\underline{47.61}$ & $\underline{72.08}$ & $\underline{1.53}$ & $\underline{3.06}$ \\
\hline$\overline{1981-1986}$ & $\overline{25.92}$ & $\overline{28.52}$ & $\overline{16.34}$ & $\overline{26.08}$ & $\overline{1.58}$ & $\overline{2.07}$ \\
\hline $1987-1990$ & 110.56 & 118.99 & 33.33 & 51.72 & 1.37 & 2.68 \\
\hline $1981-1990$ & 59.78 & 64.71 & 23.13 & 36.34 & 1.49 & 2.31 \\
\hline
\end{tabular}




\begin{tabular}{lllllll|} 
Funds & & & & \\
1981 & 730.94 & 1129.38 & 415.00 & 767.29 & 61.46 & 100.05 \\
1982 & 717.58 & 1001.83 & 448.30 & 841.13 & 78.84 & 101.16 \\
1983 & 698.52 & 1061.70 & 404.06 & 756.91 & 61.89 & 89.59 \\
1984 & 676.79 & 1017.96 & 430.36 & 814.23 & 60.02 & 96.61 \\
1985 & 911.81 & 1421.24 & 553.44 & 970.55 & 52.09 & 86.71 \\
1986 & 1232.61 & 1722.10 & 577.56 & 1051.35 & 57.54 & 103.05 \\
1987 & 1530.71 & 2098.97 & 636.88 & 1169.22 & 55.07 & 92.92 \\
1988 & 1505.74 & 1874.55 & 553.14 & 921.09 & 54.02 & 75.96 \\
1989 & 2047.30 & 2498.91 & 636.28 & 966.15 & 52.99 & 66.54 \\
1990 & $\underline{2492.72}$ & $\underline{2838.04}$ & $\underline{791.63}$ & $\underline{1119.80}$ & $\underline{61.42}$ & $\underline{71.46}$ \\
$1981-1986$ & 828.04 & 1225.70 & 471.45 & 866.91 & 61.97 & 96.20 \\
$1987-1990$ & 1894.12 & 2327.62 & 654.48 & 1044.07 & 55.88 & 76.72 \\
$1981-1990$ & 1254.47 & 1666.47 & 544.67 & 937.77 & 59.53 & 88.41 \\
\hline
\end{tabular}

${ }^{1}$ Labor is measured in terms of number of employees on payroll by the end of the respective year. The table reports sample statistics of bank outputs and inputs for different banking forms in the sample: (1) State banks, banks that are owned predominantly by the Turkish taxpayers and voters; (2) Private banks, banks whose more than $50 \%$ of shares is owned by the Turkish residents; (3) Foreign banks, banks whose more than $50 \%$ of shares is owned by the residents of foreign countries. Outputs: (1) Short-term loans, ST Loans, and (2) Long-term loans, LT Loans: the loans with less than and more than a year maturity, respectively; (3) risk-adjusted off-balance sheet items, OFF-B/S: guarantees and warranties (letters of guarantee, bank acceptance, letters of credit, guaranteed pre-financing, endorsements and others), commitments, foreign exchange and interest rate transactions as well as other off-balance sheet activities; (4) other earning assets, OEA: loans to special sectors, loans sold in interbank market and investment security portfolios (treasury bills, government bonds and other securities). Inputs: (1) Labor: the quantity of labor by the number of full-time employees on the payroll; (2) Capital: the book value of premises and fixed assets; (3) Funds: the sum of deposit (demand and time) and non-deposit funds as of the end of the respective year. OFF-B/S activities of Turkish banks became available to the public beginning from 1986.

Table 2 presents the summary statistics of inputs and outputs for public banks, private banks and foreign banks for the entire study period (1981-1990). As can be seen from the table, reform agenda has been successful in attracting new banks to the system. The number of bank entries during the period, especially from foreign banks, is impressive. There was no foreign bank entry between 1975-1980. However, the number of foreign owned banks operating in Turkey more than quadrupled between 1980-1990. Despite their small market share, foreign bank entry in large numbers affected the banking behavior of domestic banks positively, as foreign banks improved the quality of manpower and introduced new techniques and practices to the Turkish banking market (Akcaoglu, 1998; Denizer, 1997; Isik and Hassan, 2002). Indeed, the empirical results from an 80-country study (Claessens et al., 1998) indicate that the number of foreign entrants matters rather than their market share. Apparently, foreign banks affect local bank competition upon entry rather than after they have gained substantial market share.

\section{Empirical Results And Analysis}

Figures 1.1, 1.2 and 1.3 illustrate historical developments on the averages of TFPCH, TECCH and EFFCH scores between 1981-1990, respectively, for public, private and foreign banks. The line passing from 1.0 on the $y$ axis in these figures is the "demarcation line". The points above this line indicate improvement whereas the points below it indicate deterioration in the relevant index between two periods. Figure 1.1 shows that the productivity growth of foreign banks far outweighs that of private banks, whose productivity growth in turn outperforms that of public banks, for the most parts of the period. Another interesting observation is that there is an apparent positive shift after 1986 and a clear convergence towards the end of the period in the productivity growth indices of those banks. Although Figure 1.2 provides a highly volatile picture, the dominance of efficiency changes in driving productivity growth in Turkish banking is very obvious from this figure, as efficiency change indices of all forms of banks sail incessantly above the demarcation line after 1985. On the other hand, Figure 1.3 that depicts technology changes in Turkish banks suggests that the progress in technology is unimpressive throughout the period except for a few blinks from foreign banks at the onset and at the end of the period.

Our analysis shows that productivity growth in banking sector coincided with promotion of liberal policies in the 1980s. In essence, these developments observed in the productivity and efficiency measures depend on the changes in the underlying bank outputs and inputs. In other words, the positive outcome we observed in the 
productivity of Turkish banks during liberalization was brought in by the developments in bank inputs and outputs in this era. Although it is a relative measure, the Malmquist index of a bank in a certain period is closely related to the ratio of its "virtual outputs" to its "virtual inputs":

$$
M=\frac{q_{1}(\text { STLoans })+q_{2}(\text { LTLoans })+q_{3}(\text { OEA })+q_{4}(\text { OFF }-B / S)}{p_{1}(\text { Labor })+p_{2}(\text { Capital })+p_{3}(\text { Funds })}
$$

With the help of the DEA, a mathematical programming technique, we obtained the weights of outputs, $q_{1}$ to $q_{4}$, and the weights of inputs, $p_{1}$ to $p_{3}$. In the above form, it is obvious that productivity growth directly originates from the changes in the levels of inputs and outputs. For instance, $M$ can increase if outputs increase proportionately more than inputs or if inputs decrease proportionately more than outputs. Liberalization affects bank productivity by its condensed effects on those inputs and outputs. Hence, one essential question is the changes in what factors of production and what types of bank services mostly drove the productivity growth and efficiency change observed in different forms of banks during the liberalization of markets in Turkey.

Table 2 presents the correlation coefficients between the Malmquist indices and the changes in bank inputs and outputs for all forms banks between 1982-90. In general, one would expect that productivity growth should be positively correlated with the increases in outputs holding inputs fixed and negatively correlated with the increases in inputs holding outputs fixed. However, this may be not true for all cases. For example, one may also expect that increases in capital inputs be positively correlated with productivity growth, if such capital increases are mostly in the area of automation and computerization. On the other hand, because those investments inflate the level of inputs in the denominator, if they cannot bring about higher levels of outputs given their expensive acquisition costs, they could cause a reduction in productivity. The same propositions are also valid for other input factors. Our data do not contain information regarding the IT investments of Turkish banks. Thus, capital input in our model encompasses increases in all types of fixed assets, productive and non-productive. Thus, it is hard to form a prior expectation, thus we leave the final judgment to the data.

Figure 1. Changes In The Productivity, Efficiency And Technology Of Turkish Banks By Ownership

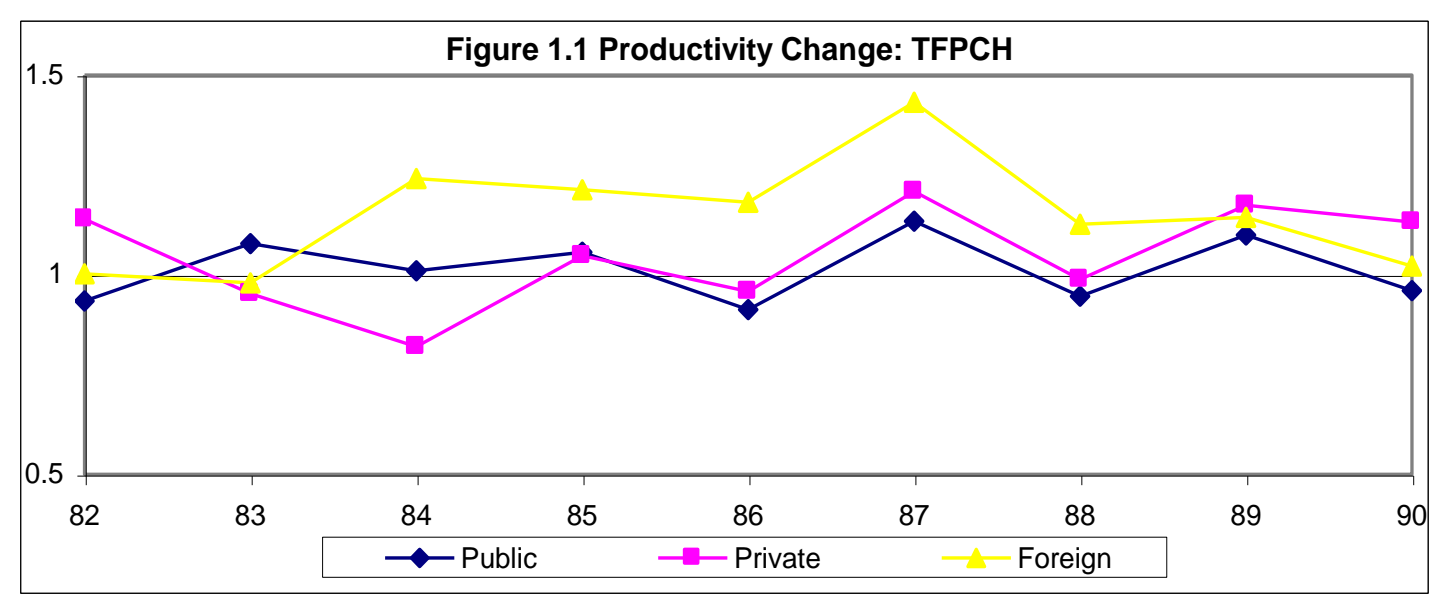



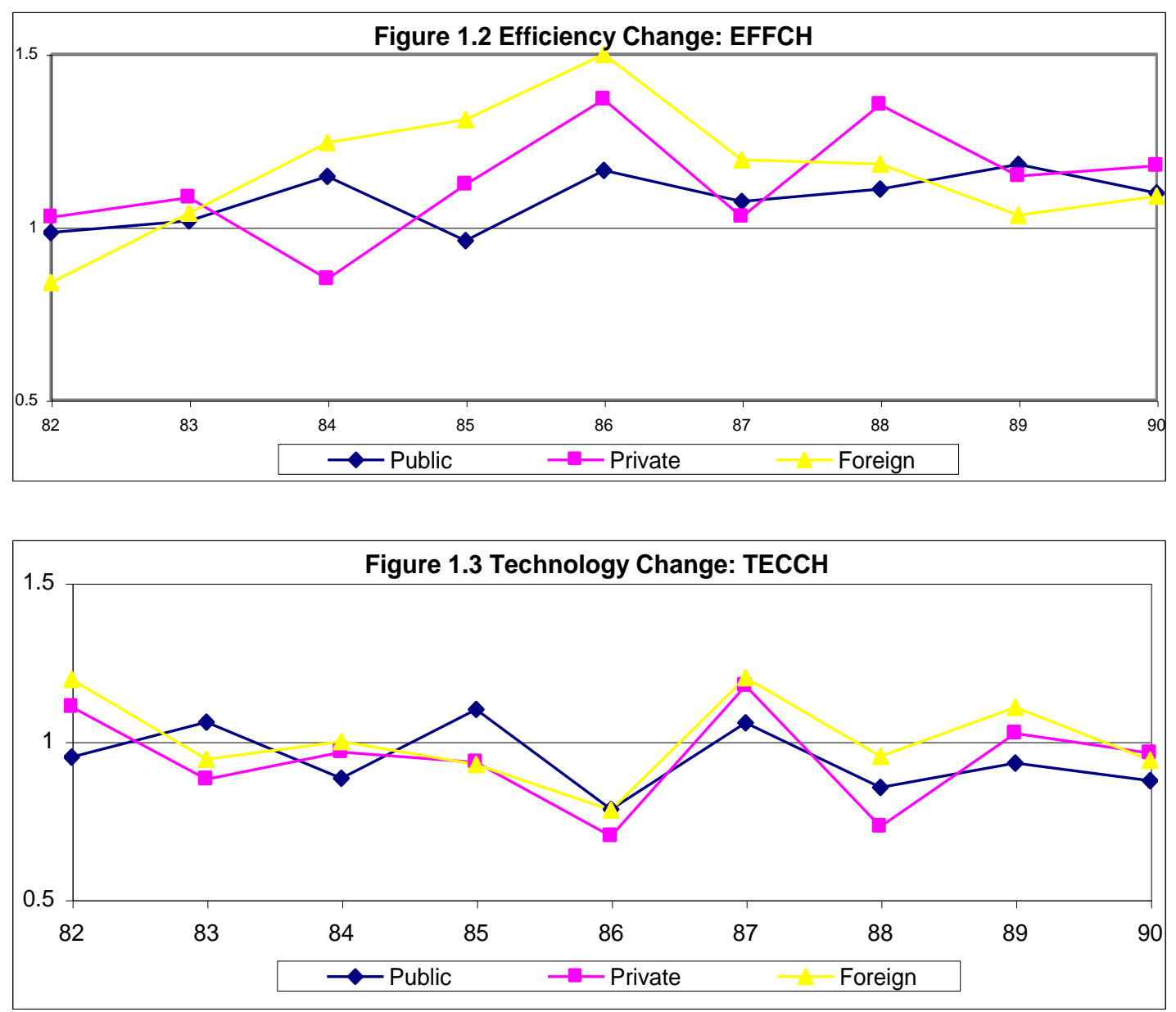

Among outputs, productivity growth in public banks is highly positively correlated with the changes in long-term loans whereas it is negatively correlated with the changes in short-term loans and off-balance sheet activities. As for private banks, productivity growth is positively correlated mostly with the changes in short-term loans, then with the changes in long-term loans, other earning assets and off-balance sheet items, respectively. The highest correlation of productivity growth in foreign banks is with the changes in off-balance sheet activities, then with the changes in short-term loans. As it seems, the correlation between productivity growth and the changes in short-term loans is highly negative in public banks and highly positive in private and foreign banks. In the inflationary environment of Turkey, because of interest rate risk, private banks prefer to extend mostly short-term loans.

In addition, the production of long-term loans is more costly than short-term loans. With their social missions, public banks produce the majority of long-term loans in Turkey. For this reason, the productivity growth in private banks may be mostly related with short-term loans. Productivity growth in all forms of banks is negatively correlated with the changes in all inputs except for funds. This suggests that increases in capital and labor factors do not bring more proportionate increases in outputs in Turkish banks. The positive correlation between the changes in productivity and the changes in funds suggest that expansion of funds may lead to expansion in the portfolio of bank products and services, which result in higher productivity. Because a bank cannot make loans more than its funds, increase in funds must be a positive externality for outputs of banks. More funds may mean more customers with many banking needs. Technological change is mostly correlated with the changes in long-term loans in public banks, and with the changes in short-term loans in private banks, and with the changes in off-balance sheet items in 
foreign banks. Efficiency change is mainly related to the changes in short-term loans in private banks, to the changes in off-balance sheet activities in foreign banks and to the changes in other earning assets in public banks. Apparently, off-balance sheet items mostly enhance the productivity, technology and efficiency of foreign banks. Scale efficiency changes are generally negatively correlated with the changes in outputs for all forms of banks.

Table 3. Correlation Of Productivity Growth (TFPCH) And Its Components (TECCH, EFFCH, PEFFCH, SCH) With Changes In Outputs And Inputs Of The Turkish Public, Private And Foreign Banks ${ }^{1}$

\begin{tabular}{|c|c|c|c|c|c|}
\hline & $\begin{array}{l}\text { Productivity } \\
\text { Change } \\
\text { (TFPCH) }\end{array}$ & $\begin{array}{l}\text { Technological } \\
\text { Change } \\
\text { (TECCH) }\end{array}$ & $\begin{array}{l}\text { Efficiency } \\
\text { Change } \\
\text { (EFFCH) }\end{array}$ & $\begin{array}{l}\text { Pure Efficiency } \\
\text { Change (PEFFCH) }\end{array}$ & $\begin{array}{l}\text { Scale } \\
\text { Change } \\
\text { (SCH) }\end{array}$ \\
\hline \multicolumn{6}{|c|}{$\begin{array}{l}{ }_{\text {A IN }} \text { BANK } \\
\text { OUTPUTS }\end{array}$} \\
\hline \multicolumn{6}{|l|}{$\underline{\Delta S T \text { Loans }}$} \\
\hline$\overline{\text { Public banks }}$ & -0.203 & -0.189 & -0.069 & -0.123 & 0.074 \\
\hline Private banks & 0.548 & 0.113 & 0.362 & 0.465 & -0.114 \\
\hline Foreign banks & 0.349 & 0.146 & 0.171 & 0.198 & -0.029 \\
\hline Industry & 0.387 & 0.045 & 0.252 & 0.314 & -0.055 \\
\hline \multicolumn{6}{|l|}{$\triangle$ LT Loans } \\
\hline Public banks & 0.253 & 0.249 & 0.042 & 0.003 & 0.033 \\
\hline Private banks & 0.437 & 0.053 & 0.345 & 0.381 & -0.114 \\
\hline Foreign banks & -0.036 & -0.113 & 0.025 & -0.009 & 0.040 \\
\hline Industry & 0.282 & 0.076 & 0.204 & 0.203 & 0.011 \\
\hline \multicolumn{6}{|l|}{$\underline{\triangle O E A}$} \\
\hline Public banks & 0.019 & -0.070 & 0.094 & -0.040 & 0.121 \\
\hline Private banks & 0.256 & 0.096 & 0.136 & 0.174 & -0.040 \\
\hline Foreign banks & 0.073 & 0.163 & -0.046 & 0.054 & -0.226 \\
\hline Industry & 0.191 & 0.080 & 0.092 & 0.124 & -0.046 \\
\hline \multicolumn{6}{|l|}{$\triangle O F F-B / S$} \\
\hline$\overline{\text { Public banks }}$ & -0.106 & 0.049 & -0.106 & 0.060 & -0.158 \\
\hline Private banks & 0.135 & 0.190 & 0.073 & 0.073 & -0.083 \\
\hline Foreign banks & 0.557 & 0.545 & 0.337 & 0.555 & -0.078 \\
\hline Industry & 0.314 & 0.355 & 0.107 & 0.162 & -0.081 \\
\hline $\begin{array}{lrl}\triangle & I N & B A N \\
\text { INPUTS } & \end{array}$ & & & & & \\
\hline \multicolumn{6}{|l|}{$\triangle$ Labor } \\
\hline Public banks & -0.115 & 0.008 & -0.093 & -0.116 & -0.010 \\
\hline Private banks & -0.084 & -0.097 & -0.014 & 0.028 & -0.067 \\
\hline Foreign banks & -0.271 & -0.034 & -0.240 & -0.271 & 0.032 \\
\hline Industry & -0.101 & -0.065 & -0.044 & -0.025 & -0.042 \\
\hline \multicolumn{6}{|l|}{$\Delta$ Capital } \\
\hline Public banks & -0.098 & 0.100 & -0.138 & -0.218 & 0.058 \\
\hline Private banks & -0.167 & -0.238 & -0.067 & -0.082 & 0.049 \\
\hline Foreign banks & -0.279 & -0.160 & -0.171 & -0.242 & 0.183 \\
\hline Industry & -0.129 & -0.07 & -0.084 & -0.128 & 0.072 \\
\hline \multicolumn{6}{|l|}{$\underline{\Delta \text { Funds }}$} \\
\hline Public banks & -0.136 & -0.093 & -0.091 & -0.165 & 0.091 \\
\hline Private banks & 0.219 & 0.081 & 0.085 & 0.163 & -0.115 \\
\hline Foreign banks & 0.197 & -0.009 & 0.141 & 0.104 & 0.059 \\
\hline Industry & 0.170 & 0.028 & 0.075 & 0.108 & -0.040 \\
\hline
\end{tabular}

1. Pearson correlation coefficients between the variables are based on the pooled data from 1981 to 1990 . Whereas, correlations including offbalance sheet items are for the pooled data from 1986 to 1990 due to unavailability of such data before 1986. 


\section{Conclusion}

This paper employs a DEA-type Malmquist index approach to evaluate the impact of financial liberalization on the productivity changes of public, private and foreign banks in Turkey during the period between 1981 and 1990. The results indicate that all forms of banks have benefited from financial liberalization period. However the response was different across different ownership forms. Due to their relatively smaller size and more dynamic structure, foreign banks and private banks reacted better to liberalization. Foreign banks were found to be the most productive, followed by private banks and public banks respectively. It also seems that productivity growth indices of all banks converge towards the end of financial sector liberalization period.

The productivity growth in public banks is driven mostly by efficiency increases stemming mainly from scale improvements. The productivity growth in private banks is also mostly fueled with efficiency changes originating mainly from scale changes. In contrast, foreign banks owe their productivity growth mostly to technological changes rather than efficiency changes. Unlike in domestic banks, efficiency increases in foreign banks mainly originate from better resource management practices rather than scale changes.

During liberalization period, increased funding costs, technical advances and competitive pressures forced domestic bank managers to contract the scale of their operations by trimming excess labor and unprofitable branches. The downsizing policies of domestic banks eventually resulted in higher productivity per employee, per dollar invested in capital, and per dollar of collected funds. On the other hand, foreign banks did not have diseconomies of scale problems, as they did not operate large network of branches. Therefore, scale improvements play lesser role in fueling foreign bank efficiency. Instead, their efficiency improvements seem to be coming mainly from technology investments and better management practices they exported from international markets. Apparently opening policies have been beneficial as lifting of entry barriers brought in efficient and productive foreign banks from which local banks could learn new systems and practices.

On the other hand, looking back to the 1980s from today, it can be argued that benefits from the financial liberalization have not been fully realized. The fact that existing oligopolistic and highly concentrated market structure was largely unaffected explains the absence of a more effective competition. Particularly in the 1990s, predominance of the public banks in the system has created an uneven playing field in the banking sector due to the fact that both their borrowing and lending operations have been politicized. Although these institutions have enjoyed the benefit of state support and public confidence with respect to safety of deposits, they emerged as major instruments of rent distribution in the political process as well. These banks were also characterized as inefficient management, inadequate staff motivation and strict labor regulations. Under a more transparent and effective system it could be seen that public banks have been carrying much larger amount of non-performing loans than private banks. This fact was clearly observed in the two big banking crises of 1990s.

Turkish banking sector could also benefit more from the presence of foreign banks. Foreign banks' activities were restricted, and limits were placed on the number of branches they could open. Foreign banks accounted for a small share of banking transactions and have had a relatively small impact on the performance of domestic institutions given that the market remained oligopolistic and segmented. However, domestic firms were able to capture productivity changes, which arose from the adoption of new technology and practices introduced by the foreign banks.

Given the relationship between macroeconomic environment and banking sector development, policy makers should be cautious in identifying policy instruments that are effective in bringing about changes in productivity and efficiency and come up with the best policy response. Macroeconomic instability can distort banking sector development and affect the performance of the banks. In the case of Turkey, among others, high inflationary environment probably affected the financial system's efficiency. From this perspective, macroeconomic stability may be a prerequisite for liberalization policies to improve the efficiency of credit allocation at the microeconomic level. 


\section{References}

1. Akcaoglu, E., 1998. Financial innovation in Turkish banking, Capital Markets Board of Turkey, Publication Number 127, Ankara, Turkey.

2. Akkurt, A., Hakioğlu, D., Karayalcin, A., 1992. Developments in the Turkish banking sector: 1980-1990. In: Aydogan, k., Ersel, H. (Eds.) Issues in Banking structure and Competition in a Changing World, Conference Proceedings. Central Bank of the Republic of Turkey, Ankara Turkey.

3. Altunbas, Y., Evans, L., and Molyneux, P., 2001. Bank ownership and efficiency. Journal of Money, Credit and Banking 33, 926-954.

4. Atiyas, I., Ersel H., 1994. The impact of financial reform: Turkish experience. In: Caprio, g., Atiyas, I., Hanson, J. (Eds.), Financial Reform: Theory and Experience. Cambridge University Press, UK.

5. Bauer, P.W., Berger, A.N., Humphrey, D.B., 1993. Efficiency and productivity growth in U.S. banking. In Fried, H.O., Lovell, C.A.K., Schmidt, S.S. (Eds.), The Measurement of Productive Efficiency: Techniques and Applications. Oxford University Press, UK, 386-413.

6. Berg, S. A., Forsund, F. R. and Jansen, E. S., 1992. Malmquist indices of productivity growth during the deregulation of Norwegian banking, 198-89. Scandinavian Journal of Economics 94, S211-S228.

7. Berger A. N. and Humphrey, D.B., 1997. Efficiency of financial institutions: International survey and directions for future research. European Journal of Operational Research 98, 175-212.

8. Berger, A. N., Hunter, W.C., and Timme, S. G., 1993. The efficiency of financial institutions: A review and preview of research past, present and future. Journal of Banking and Finance 17, 221-49.

9. Berger, A.N., Demsetz, R. S., and Strahan, P. E., 1998. The consolidation of the Financial Services Industry" Causes, consequences and implications for the future. Federal Reserve Bank of New York Staff Reports, No: 55.

10. Bhattacharya, A., Lovell, C.A.K. and Sahay, P., 1997. The impact of liberalization on the productive efficiency of Indian commercial banks. European Journal of Operational Research 98, 332-345.

11. Charnes, A., Cooper, W. W., and Rhodes, E., 1978. Measuring the efficiency of decision making units. European Journal of Operations Research 2, 429-444.

12. Claessens, S., Demirguc-Kunt, A., and Huizinga, H., 1998. How does foreign bank entry affect the domestic bank market? Mimeo, World Bank.

13. Denizer, C., 1997. The effects of financial liberalization and new bank entry on market structure and competition in Turkey. World Bank Development Research Group working paper.

14. Denizer, C., 1999. Foreign entry in Turkey's banking sector, 1980-97. World Bank Development Research Group, working paper.

15. Elyasiani, E. and Mehdian, S., 1995. The comparative efficiency performance of small and large U.S. commercial banks in the pre- and post-deregulation eras. Applied Economics 27, 1069-1079.

16. Fare, R., Grosskopf, S., Lindgren, B., and Roos, P., 1992. Productivity changes in Swedish pharmacies 1980-1989: A nonparametric Malmquist approach. Journal of Productivity Analysis 3(3), 85-101.

17. Fare, R., Grosskopf, S., Norris M. and Zhang, Z., 1994. Productivity growth, technical progress, and efficiency change in industrialized countries. The American Economic Review, vol.84, no.1, 66-83.

18. Farrell, M.J., 1957. The measurement of productive efficiency. Journal of the Royal Statistical Society, A CXXX, Part 3, 253-290.

19. Gilbert, R. A. and Wilson, P. W., 1998. Effects of deregulation on the productivity of Korean banks. Journal of Economics and Business 50, 133-155.

20. Grifell-Tatje, E. and Lovell, C.A.K., 1997. Deregulation and productivity decline: The case of Spanish savings banks. European Economic Review 40, 1281-1303.

21. Humphrey, D.B. 1993. Cost and technical change: Effects from bank deregulation. Journal of Productivity Analysis 4, 5-34.

22. Humphrey, D.B. and Pulley, L.B., 1997. Banks' responses to deregulation: Profits, technology, and efficiency. Journal of Money, Credit, and Banking 29, 73-93.

23. Isik, I. and Hassan, M.K. (forthcoming). Financial Disruption and Bank Productivity: The 1994 Experience of Turkish Banks, Quarterly Review of Economics and Finance.

24. Isik, I., and Hassan, M.K., 2002. Cost and profit efficiency of the Turkish banking industry: An empirical investigation. The Financial Review 37, 257-280. 
25. Kasman, A. (2002). Cost inefficiency, scale economies and technological progress in Turkish banking. Central Bank Review 1, 1-20.

26. Leightner, J.E. and Lovell, C.A.K., 1998. The impact of financial liberalization on the performance of Thai banks. Journal of Economics and Business 50, 115-131.

27. Lozano, A., 1995. Efficiency and technical change for Spanish banks. Applied Financial Economics 8, 289300 .

28. Malmquist, S., 1953. Index numbers and indifference surfaces. Trabajos de Estadistica 4, 209-42.

29. Noulas A.G., 2001. Deregulation and operating efficiency: the case of the Greek banks. Managerial Finance 8, 35-47

30. Sathye M,. 2002. Measuring productivity changes in Australian banking: an application of Malmquist indices, Managerial Finance 9, 48-58.

31. Shephard, R.W., 1970. The theory of cost and production functions. Princeton: Princeton University press.

32. Shyu, J., 1998. Deregulation and bank operating efficiency: An empirical study of Taiwan's banks. Journal of Emerging Markets, 3, 1, 27-46.

33. Tornqvist, L., 1936. The bank of Finland's consumption price index. Bank of Finland Monthly Bulletin 10, $1-8$.

34. Yulek, M.A., 1998. Financial liberalization and the real economy: The Turkish experience. Capital Markets Board of Turkey, Publication Number 110, Ankara, Turkey.

35. Zaim, O., 1995. The effect of financial liberalization on the efficiency of Turkish commercial banks. Applied Financial Economics 5, 257-64.

Notes 